Progress. Agric. 18(2) : 81-91, 2007

ISSN 1017-8139

\title{
EFFECT OF EARTHING UP AND LEVEL OF IRRIGATION ON YIELD AND QUALITY SEED PRODUCTION OF ONION
}

\author{
M. K. Ali, M. N. Alam, M. A. B. Barkotulla, S. M. A. T. Khandaker ${ }^{1}$ and \\ P. W. Simon ${ }^{2}$ \\ Department of Crop Science and Technology, University of Rajshahi \\ Rajshahi, Bangladesh
}

\begin{abstract}
A field experiment was conducted during the period from October 2001 to April 2002 to study the effect of earthing up and level of irrigation on yield and quality seed production of onion (cv. Taherpuri) at Rajshahi University campus, Rajshahi, Bangladesh. Two different factors were considered, factor (A): Earthing up $\left(E_{1}\right)$, without earthing up $\left(E_{0}\right)$ and factor $(B)$ : irrigation level (5 levels) viz. irrigation start at $1^{\text {st }}$ time and when required $\left(\mathrm{I}_{4}\right)$, irrigation start at $40 \mathrm{DAP}$ and when required $\left(\mathrm{I}_{3}\right)$, irrigation start at $60 \mathrm{DAP}$ and when required $\left(I_{2}\right)$, irrigation start at $80 \mathrm{DAP}$ and when required $\left(\mathrm{I}_{1}\right)$, no irrigation or control $\left(\mathrm{I}_{0}\right)$. The standard dose of cowdung and NPK were applied according to HRDP (1995). The factorial experiment was laid out following at Split Plot Design (SPD) with three replications. The result revealed that bulb emergence, plant height number of leaves, length of scape, tillers, seeded fruits, fruits set, days to blooming, seed yield, 1000-seed weight and germination percentage were significantly influenced by different treatments. The highest seed yield $(405.97 \mathrm{~kg} / \mathrm{ha})$ was found from earthing up with irrigation start at first time and when required $\left(E_{1} I_{4}\right)$ followed by $E_{1} I_{3}$ $(347.37 \mathrm{~kg} / \mathrm{ha}), \mathrm{E}_{0} \mathrm{I}_{4}(330.73 \mathrm{~kg} / \mathrm{ha})$ compared with other treatments. The results suggested that earthing up with 3-4 times irrigation is more effective for onion seed production in Bangladesh.
\end{abstract}

Key Words : Allium cepa, Earthing up, Irrigation timing, Onion, Seed production

\section{INTRODUCTION}

Onion (Allium cepa L.) is belonging to the family Alliaceae is one of the most important spice as well as vegetables crops in the world including Bangladesh. Among the spices crops grown in Bangladesh onion ranks top in respect of production and second in respect of area. It is estimated that the yearly requirement of onion is about 5 lakh mt., but the domestic production is only about 1.5 lakh tones. To meet up the shortage a huge quantity of onion is being imported each year. It grows in almost all the districts of Bangladesh. Thus the average per hectare yield comes to about 4.12 metric tons which is quite low in comparison with that of the other countries like China, India, and

\footnotetext{
1 Soil Resources Development Institute, Shyampur, Rajshahi, Bangladesh

2 Department of Horticulture, Wisconsin University, Madison, USA
} 
Pakistan where per hectare yields are respected to be 15.22, 10.43 and 12.17 tons respectively (FAO, 1999). Onion is the second important crop among the vegetables after tomato. In Bangladesh onion has been an integral part of the people's daily diet and its use is very common in almost all food preparations (Hossain and Islam, 1994). Medicinal value of this spice crop is helpful for human being and it has also preservative.

Onion is a biennial crop in the temperate zones. For its seed production it needs proper management practices. Onion bulbs are produced in all districts of Bangladesh but seed produced by a small number of farmer areas of Faridpur, Natore and Rajshahi. (Rahim et al., 1993). Although the climate of Bangladesh is congenial to the production of high quality onion seed, farmers are not making use of modern technology for its production, (Bokshi et al., 1989). Some farmers follow conventional methods for raising onion seed crop and use limited irrigation or not at all. But literature indicate that the use of irrigation could improve yield and quality of seed to a great extend (Brown et al., 1977; Shasha et al., 1986; Bhonde et al., 1989).

For having a successful crop, frequent irrigations is needed. But at present, in the places where onion is cultivated, irrigation facilities are not easily available. Moreover, irrigation increase the cost of production of onion. So, earthing up was thought to be helpful in this situation. The well known benefits that earthing up provides are regulating soil moisture and temperature, suppress the weeds, improving germination and emergence etc. high yield and quality, prolonged growing season higher nutritive value of the produce, improved storability etc. are also well described advantages of earthing up, therefore, aids in reducing cost involved in crop production with irrigation. This would also improve the seed quality of onion. To overcome the above adverse conditions, research work was undertaken to the effect of earthing up and level of irrigation on yield and quality seed production of onion in calcareous soils of Bangladesh.

\section{MATERIALS AND METHODS}

The field experiment was conducted at Rajshahi University Campus, Bangladesh during October 2001 to April 2002. The soil sample was analyzed following ASI method (Hunter, 1984). The soil was "silty clay loam" in texture with $\mathrm{pH} 7.8$, organic carbon $1.0 \%$, total $\mathrm{N}$ $0.12 \%$, available P 15.0 ppm, K 0.12 (me\%). The soil was medium fertile and very low content of $\mathrm{N}$ but medium content of $\mathrm{P}$. Two different factors were considered, factor (A): Earthing up ( $\left.E_{1}\right)$, without earthing up $\left(E_{0}\right)$ and factor $(B)$ : Irrigation level (5 levels) viz. irrigation start at $1^{\text {st }}$ time and when required $\left(\mathrm{I}_{4}\right)$, irrigation start at 40 DAP and when required $\left(\mathrm{I}_{3}\right)$, irrigation start at $60 \mathrm{DAP}$ and when required $\left(\mathrm{I}_{2}\right)$, irrigation start at $80 \mathrm{DAP}$ and when required $\left(\mathrm{I}_{1}\right)$, no irrigation or control $\left(\mathrm{I}_{0}\right)$. The standard dose of cowdung and NPK was followed by HRDP, 1995. The 2 factorial experiments were laid out following at Split Plot Design (SPD) with three replications. The land was ploughed and crossploughed several times by a power tiller to obtain a good tilth. The whole amount of cowdung and triple super phosphate were applied before bulb planting and urea were 
used at 30, 45and $60 \mathrm{DAP}$ as the source of nitrogen. The whole experimental area $6.5 \mathrm{~m} \times$ $20.0 \mathrm{~m}$ which was divided into 3 blocks, each block was subdivided in 10 plots and hence there were in total 30 unit plots. The size of each unit plot was $1 \mathrm{~m} \times 1 \mathrm{~m}$. Five shallow furrows per plot at distance of $20 \mathrm{~cm}$ were made in each plot. Dry set of onion about 6-7g weight of a local cv. Taherpuri were planted as per treatment and layout and covered with loose soil. Initially light irrigation was done with watering can. 25 plants/plots were to grow ultimately. Weeding was done as and when necessary. The field was irrigated by flood method. Dimecron scw at the rate of $2 \mathrm{~kg}$ per hectare was sprayed around each unit plot as precautionary measure against different insect (Thrips and cutworms). Precautionary measures against purple blotch were taken by spraying Rovral 50wp the rate of $2 \mathrm{~g}$ per Liter water and when required. Harvest was done by hand when most of the umbels were exposed their black seeds and 20-30\% capsule were splitted (Pandey et al. 1992). Umbels were harvested in the morning to prevent shattering of seed. The data pertaining to growth and yield that is bulb emergence $(\%)$, plant height $(\mathrm{cm})$, number of leaves per plant, length of scape $(\mathrm{cm})$, Tillers per plant flowers per umbel, fruits set./ umbel, Percentage of fruit set per umbel, Days to scape formation, blooming, Days to seed harvest, seed yield/umbel (g), seed yield/plant (g), seed yield/plot (g) and per hectare $(\mathrm{kg}), 1000$ seed weight and germination rate. Data were statistically analyzed and the mean values recorded for all the treatments were compared by DMRT along with the estimation of LSD values following Gomez and Gomez (1984).

\section{RESULTS AND DISCUSSION}

The results on different parameters of the presents experiment have been presented and discussed under the following headings.

\section{Bulb emergence}

The effect of irrigation and earthing up was significantly influenced on bulb emergence (Table 1). The minimum time (6.47 days) was obtained from earthing up plants and maximum time (7.58 days) was required from non-earthing up plants. The 50\% emergence of bulbs was observed at 5.62 days and it was significantly similar of all treatment except irrigation start at planting time and when required. The combined effect between earthing up and irrigation on the percentage of bulb emergence was found significant (Table 1). The lowest time (4.50 days) was found from irrigation start at planting time and when required with earthing up and highest time (8.20 days) was found from irrigation start at $80 \mathrm{DAP}$ without earthing up and it was statistically similar of all treatments except $\mathrm{E}_{0} \mathrm{I}_{4}$ and $\mathrm{E}_{1} \mathrm{I}_{3}$ treatment combination. Onion is a shallow rooted plant so it needs continuations moisture supply to the soil. In non-irrigated plots, a gradual removal of available water from soil was observed by MacGillivray (1948).

\section{Plant height}

Earthing up significantly affected the height of onion plant, measured at different days after planting. Maximum plant height was obtained from earthing up at 30, 45 and 60 DAP. Plant height increased with the advancement of time from 30 to 60 days after planting. At $60 \mathrm{DAP}$, maximum plant height $(61.46 \mathrm{~cm})$ was found from in the plot which 
was earthing up compared to control (Table 1). Different irrigation level showed significant variation in relation to the plant height. Maximum plant height $(67.93 \mathrm{~cm})$ was found in the plant that received irrigation start at first time and when required at $60 \mathrm{DAP}$ and lowest was $(52.25 \mathrm{~cm})$ found in the plant which control, followed by irrigation start at 40,60 and 80 DAP and when necessary. The combined effect of earthing up and irrigation was significant in relation to plant height (Table 1) at 30, 45 and 60 days after planting. At 30 to $60 \mathrm{DAP}$, plant height was increased with advancement of time. At 60 DAP, the highest plant $(69.77 \mathrm{~cm})$ was found in the plant which was earthing up with irrigation start at first time and when required it was statistically identical with irrigation start at 40,60 and 80 DAP and when required with earthing up and irrigation start at first time and when required without earthing up. The lowest plant height was found $(47.85 \mathrm{~cm})$ from control plot and it was similar all the treatment except $\mathrm{E}_{1} \mathrm{I}_{4}$ and $\mathrm{E}_{1} \mathrm{I}_{3} \& \mathrm{E}_{0} \mathrm{I}_{4}$ treatment combination. Patil et al. (1993) also reported that irrigation increased the number of leaves per plant in onion plants. Jonassen (1983) reported that irrigation increased height of flowering stalk of onion seed crop.

\section{Number of leaves}

The number of leaves per plant was observed to vary significantly between earthing up and non earthing up at different days after planting (Table 1). The number of leaves per plant increased with the passing of time. Maximum number of leaves per plant (13.07) was recorded the plant which was earthing up and different from control plant at 60 DAP. Different level of irrigation was significantly effect on number of leaves at 45 and 60 DAP (Table 1). The highest number of leaves (15.95) per plant was found from irrigation start at first time and when required and lowest number of leaves come from control plant, followed by irrigation start at 60 and $80 \mathrm{DAP}$ and when required. The interaction of earthing up and irrigation were not significant but their combination was significant in relation to number of leaves per plant at 45 and 60 DAP (Table 1). At 60 $\mathrm{DAP}$, the highest number of leaves (16.49) was recorded from treatment combination $\mathrm{E}_{1} \mathrm{I}_{4}$ which was statistically similar with $\mathrm{E}_{1} \mathrm{I}_{3}$ and $\mathrm{E}_{0} \mathrm{I}_{4}$ combination. The lowest number of leaves (9.41) was found from $E_{0} I_{0}$ which was statistically identical with $E_{1} I_{1}, E_{0} I_{2}$ and $E_{0} I_{1}$ treatment combination.

\section{Length of scape}

Maximum length of scape $(62.21 \mathrm{~cm})$ was found from having earthing up and minimum length of scape $(57.51 \mathrm{~cm})$ was recorded from having no earthing up. On the other hand, the highest length of scape $(71.15 \mathrm{~cm})$ was found from irrigation start at first time and when required which was statistically similar of irrigation start at 40 DAP and when required and there was different from all other treatment. The lowest length of scape $(50.97 \mathrm{~cm})$ was found from control irrigation it was similar with start at 60 and 80 DAP irrigation applied.

In the combined effect, the tallest length of scape $(73.00 \mathrm{~cm})$ was found from $\mathrm{E}_{1} \mathrm{I}_{4}$ combination which was statistically similar with $\mathrm{E}_{1} \mathrm{I}_{3}, \mathrm{E}_{0} \mathrm{I}_{4}$ and $\mathrm{E}_{0} \mathrm{I}_{3}$ whereas the lowest length of scape $(48.17 \mathrm{~cm})$ was found from control $\left(\mathrm{E}_{0} \mathrm{I}_{0}\right)$. The flowering stalk is an apical 
extension of the stem and the region between the inflorescence bracts (spathe) and the upper most foliage leaf is the only internodes which elongates during the life of the plants (Jones and Mann, 1963).

\section{Number of tillers per plant}

There was a significant variation in earthing up, irrigation and their interaction effect in relation to tillers per plant (Table 2). Maximum tillers (2.28) was found having earthing up and minimum was observed having no earthing up. In respect of irrigation, the maximum tillers (2.82) was found from irrigation start at first time and when necessary and minimum tillers (1.53) was recorded from control plant. The interaction effect was to be found significant difference in respect of tillers. The maximum tillers per plant (2.92) was recorded from treatment combination $\mathrm{E}_{1} \mathrm{I}_{4}$ and minimum tillers (1.23 and 1.51) were found from $\mathrm{E}_{0} \mathrm{I}_{0}$ and $\mathrm{E}_{0} \mathrm{I}_{1}$ treatment combination. Depending on genotype bulb size and environmental conditions a single mother bulb can produce from 1 to approximately 30 inflorescences but 5 to 7 is the common number (Mital and Srivastava, 1964). This is close agreement with the present study.

\section{Flowers per umbel}

There was a significant variation among earthing up and irrigation but their interaction effect was not significant (Table 2). Maximum flowers (183.48) was fond from earthing up was applied whereas minimum flowers (168.41) was observed from non-earthing up. The highest flowers (182.31) was found from irrigation start at first time and when necessary followed by irrigation start at 40,60 and $80 \mathrm{DAP}$ and when required compared to that of control irrigation. In the interaction effect in relation to flowers number, the highest flowers (190.83) was found from treatment combination $E_{1} I_{2}$ and the lowest flower number (148.17) was found from control irrigation.

\section{Fruits set per umbel}

In earthing up, maximum fruits set (84.89) per umbel was recorded from having earthing up and minimum fruits set per umbel (65.62) was found from having no earthing up. In respect of irrigation, the highest fruits set per umbel (107.90) was found form irrigation start at $40 \mathrm{DAP}$ and when required followed by irrigation start at first time and when required. The lowest fruit set (35.99) per umbel was found from control irrigation. In the interaction effect of earthing up and irrigation, the highest fruits set (120.27) was recorded from treatment combination $\mathrm{E}_{1} \mathrm{I}_{4}$, followed by $\mathrm{E}_{1} \mathrm{I}_{3}$ whereas the lowest fruits set per umbel (28.85) was found from $\mathrm{E}_{0} \mathrm{I}_{0}$ and it was statistically similar with $\mathrm{E}_{1} \mathrm{I}_{0}$ treatment combination. Globerson et al. (1987) reported that irrigation during flowering gave maximum fruit set and excess water reduced the number of fruit set per umbel.

\section{Percentage of fruit set per umbel}

The maximum percentage of fruit set $(45.93 \%)$ was found in earthing up and the minimum percentage of fruit set $(38.41 \%)$ was found in non- earthing up plant. The highest percentage of fruit set $(59.43 \%)$ was found from irrigation start at $40 \mathrm{DAP}$ and when required followed by irrigation start at first time and when required whereas the 
lowest percentage of fruit set $(22.74 \%$ ) was recorded from control irrigation. In combined effect, the highest percentage of fruit set $(63.66 \%)$ was recorded from $\mathrm{E}_{1} \mathrm{I}_{3}$ treatment combination, followed by $\mathrm{E}_{1} \mathrm{I}_{4}$. The lowest percentage of fruit set $(20.00 \%)$ was observed from $\mathrm{E}_{0} \mathrm{I}_{0}$, it was statistically similar with $\mathrm{E}_{1} \mathrm{I}_{0}$ treatment combination.

Table 1. Effect of earthing up at different levels of irrigation on the growth of onion

\begin{tabular}{|c|c|c|c|c|c|c|c|}
\hline \multirow[t]{2}{*}{ Treatments } & \multirow{2}{*}{$\begin{array}{c}50 \% \text { bulb } \\
\text { emergence }\end{array}$} & \multicolumn{3}{|c|}{ Plant height $(\mathrm{cm})$} & \multicolumn{3}{|c|}{ Number of leaves per plant } \\
\hline & & $30 \mathrm{DAP}$ & $45 \mathrm{DAP}$ & $60 \mathrm{DAP}$ & $30 \mathrm{DAP}$ & $45 \mathrm{DAP}$ & $60 \mathrm{DAP}$ \\
\hline$E_{1}$ & 6.47 & 30.45 & 56.77 & 61.46 & 10.97 & 12.22 & 13.07 \\
\hline $\mathrm{E}_{0}$ & 7.58 & 27.85 & 50.52 & 54.76 & 9.53 & 10.62 & 11.83 \\
\hline LSD at $5 \%$ & 1.38 & 3.95 & 7.52 & 7.37 & 0.69 & 0.82 & 1.40 \\
\hline $1 \%$ & - & - & - & - & 1.61 & 1.89 & - \\
\hline \multicolumn{8}{|l|}{ Irrigation level } \\
\hline $\mathrm{I}_{0}$ & $7.22 \mathrm{a}$ & 26.67 & $48.26 b$ & $52.25 b$ & 9.33 & $10.18 b$ & $10.19 c$ \\
\hline $\mathrm{I}_{4}$ & $5.62 b$ & 33.45 & $63.09 a$ & $67.93 a$ & 11.17 & $13.10 \mathrm{a}$ & $15.95 a$ \\
\hline $\mathrm{I}_{3}$ & $6.98 \mathrm{a}$ & 29.23 & $54.36 b$ & $59.48 b$ & 11.17 & $12.25 \mathrm{ab}$ & $14.03 b$ \\
\hline $\mathrm{I}_{2}$ & $7.75 \mathrm{a}$ & 29.02 & $50.98 b$ & $55.34 b$ & 10.17 & $11.12 \mathrm{ab}$ & $11.79 \mathrm{c}$ \\
\hline $\mathrm{I}_{1}$ & $7.55 a$ & 27.35 & $51.54 \mathrm{~b}$ & $55.55 b$ & 9.42 & $10.45 \mathrm{~b}$ & $10.27 \mathrm{c}$ \\
\hline LSD at $5 \%$ & 0.82 & NS & 7.46 & 7.17 & NS & 1.96 & 1.64 \\
\hline $1 \%$ & 1.13 & & 10.28 & 9.88 & & - & 2.26 \\
\hline \multicolumn{8}{|c|}{ Treatment combinations } \\
\hline $\mathrm{E}_{1} \mathrm{I}_{0}$ & $7.03 \mathrm{ab}$ & 27.72 & $49.83 \mathrm{bc}$ & $56.65 \mathrm{bcd}$ & 10.50 & $11.20 \mathrm{abc}$ & 10.96de \\
\hline $\mathrm{E}_{1} \mathrm{I}_{4}$ & $4.50 \mathrm{c}$ & 36.33 & $65.00 \mathrm{a}$ & $69.77 \mathrm{a}$ & 11.33 & $13.87 a$ & $16.49 a$ \\
\hline $\mathrm{E}_{1} \mathrm{I}_{3}$ & $6.57 b$ & 30.50 & $58.33 \mathrm{abc}$ & $62.71 \mathrm{abc}$ & 11.50 & $12.60 \mathrm{ab}$ & $14.44 a b c$ \\
\hline $\mathrm{E}_{1} \mathrm{I}_{2}$ & 7.33ab & 29.33 & $55.36 \mathrm{abc}$ & $59.26 a-d$ & 11.17 & $12.00 \mathrm{abc}$ & $12.40 \mathrm{~cd}$ \\
\hline $\mathrm{E}_{1} \mathrm{I}_{1}$ & $6.90 \mathrm{ab}$ & 28.37 & $55.30 \mathrm{abc}$ & $58.90 a-d$ & 10.33 & $11.43 \mathrm{abc}$ & 11.04de \\
\hline $\mathrm{E}_{0} \mathrm{I}_{0}$ & $7.40 \mathrm{ab}$ & 25.63 & $46.68 c$ & $47.85 \mathrm{~d}$ & 8.17 & $9.17 \mathrm{c}$ & $9.41 \mathrm{e}$ \\
\hline $\mathrm{E}_{0} \mathrm{I}_{4}$ & $6.73 b$ & 30.62 & $61.18 \mathrm{ab}$ & $66.10 \mathrm{ab}$ & 11.00 & $12.33 \mathrm{ab}$ & $15.41 \mathrm{ab}$ \\
\hline $\mathrm{E}_{0} \mathrm{I}_{3}$ & 7.40ab & 27.97 & $50.38 \mathrm{bc}$ & $56.26 \mathrm{bcd}$ & 10.83 & $11.90 \mathrm{abc}$ & $13.63 b c$ \\
\hline $\mathrm{E}_{0} \mathrm{I}_{2}$ & $8.17 a$ & 28.71 & $46.59 \mathrm{c}$ & $51.42 \mathrm{~cd}$ & 9.17 & $10.23 b c$ & 11.19de \\
\hline $\mathrm{E}_{0} \mathrm{I}_{1}$ & $8.20 \mathrm{a}$ & 26.33 & $47.78 \mathrm{c}$ & $52.19 \mathrm{~cd}$ & 8.50 & $9.47 b c$ & $9.49 \mathrm{e}$ \\
\hline LSD at $5 \%$ & 1.16 & NS & 10.56 & 10.14 & NS & 2.78 & 2.32 \\
\hline $1 \%$ & 1.60 & & 14.54 & 13.98 & & 3.83 & 3.19 \\
\hline
\end{tabular}

Means followed by the same letter(s) do not statistically differ at $5 \%$ level tested by DMRT, NS = Non Significant, $\mathrm{E}_{1}=$ Earthing up, $\mathrm{E}_{0}=$ Non-earthing up, $\mathrm{I}_{0}=$ No irrigation, $\mathrm{I}_{4}=$ Irrigation start at first time and when required, $\mathrm{I}_{3}=$ Irrigation start at 40 DAP and when required, $\mathrm{I}_{2}=$ Irrigation start at $60 \mathrm{DAP}$ and when required, $\mathrm{I}_{1}=$ Irrigation start at $80 \mathrm{DAP}$ and when required

\section{Days to scape formation}

Maximum days (44.40) required to scape formation was found from non earthing up whereas minimum was found from earthing up of soil. In respect of irrigation, the longest time (47.67 days) was required from control irrigation which was statistically 
followed by irrigation start at 60 and 80 DAP and when necessary. The shortest time (35.50 days) was required from irrigation start at planting time and when necessary, followed by irrigation start at $40 \mathrm{DAP}$ and when necessary. The longest time (50.33 days) was required from $\mathrm{E}_{0} \mathrm{I}_{0}$ treatment combination whereas the shortest time (34.67 days) comes from $\mathrm{E}_{1} \mathrm{I}_{4}$ treatment combination.

Table 2. Effect of earthing up at different levels of irrigation on the seed yield and quality of onion

\begin{tabular}{|c|c|c|c|c|c|c|c|}
\hline Treatments & $\begin{array}{c}\text { Length of } \\
\text { scape }(\mathrm{cm})\end{array}$ & $\begin{array}{c}\text { Tillers/ } \\
\text { plant }\end{array}$ & $\begin{array}{c}\text { Flowers/ } \\
\text { umbel }\end{array}$ & $\begin{array}{c}\text { Seeded } \\
\text { fruits/ } \\
\text { umbel }\end{array}$ & $\begin{array}{c}\% \text { fruit } \\
\text { set/ } \\
\text { umbel }\end{array}$ & $\begin{array}{l}\text { Days to } \\
\text { scape } \\
\text { formation }\end{array}$ & $\begin{array}{l}\text { Days to } \\
\text { blooming }\end{array}$ \\
\hline $\mathrm{E}_{1}$ & 62.21 & 2.28 & 183.48 & 84.89 & 45.93 & 40.13 & 87.65 \\
\hline $\mathrm{E}_{0}$ & 57.51 & 1.99 & 168.41 & 65.62 & 38.41 & 44.40 & 89.71 \\
\hline LSD at $5 \%$ & NS & 0.28 & 21.19 & 4.56 & 4.76 & NS & NS \\
\hline $1 \%$ & & - & - & 10.53 & 10.99 & & \\
\hline \multicolumn{8}{|l|}{ Irrigation level } \\
\hline $\mathrm{I}_{0}$ & $50.97 \mathrm{c}$ & $1.53 \mathrm{e}$ & $158.71 b$ & $35.99 c$ & $22.74 c$ & $47.67 a$ & $93.32 \mathrm{a}$ \\
\hline $\mathrm{I}_{4}$ & $71.15 a$ & $2.82 \mathrm{a}$ & $182.31 \mathrm{a}$ & $99.93 a$ & $54.61 \mathrm{a}$ & $35.50 \mathrm{~b}$ & $82.35 b$ \\
\hline $\mathrm{I}_{3}$ & $64.63 \mathrm{ab}$ & $2.49 \mathrm{~b}$ & $181.84 a$ & $107.90 a$ & $59.43 a$ & $38.17 \mathrm{~b}$ & $83.57 \mathrm{~b}$ \\
\hline $\mathrm{I}_{2}$ & $55.50 \mathrm{c}$ & $2.15 c$ & $179.81 \mathrm{a}$ & $66.91 b$ & $37.06 \mathrm{~b}$ & $44.67 \mathrm{a}$ & $91.37 \mathrm{a}$ \\
\hline $\mathrm{I}_{1}$ & $57.05 b c$ & $1.67 \mathrm{~d}$ & $177.06 a$ & $65.53 b$ & $37.00 \mathrm{~b}$ & $45.33 a$ & $92.80 \mathrm{a}$ \\
\hline LSD at $5 \%$ & 8.16 & 0.13 & 15.99 & 11.90 & 7.02 & 5.56 & 4.29 \\
\hline $1 \%$ & 11.25 & 0.18 & - & 16.39 & 9.68 & 7.65 & 5.92 \\
\hline \multicolumn{8}{|c|}{ Treatment combinations } \\
\hline $\mathrm{E}_{1} \mathrm{I}_{0}$ & $53.77 \mathrm{de}$ & $1.83 \mathrm{f}$ & 169.25 & $43.14 \mathrm{ef}$ & $25.48 \mathrm{de}$ & 45.00 & $90.47 \mathrm{ab}$ \\
\hline $\mathrm{E}_{1} \mathrm{I}_{4}$ & $73.00 \mathrm{a}$ & $2.92 \mathrm{a}$ & 189.66 & $120.27 a$ & $63.58 \mathrm{a}$ & 34.67 & $81.17 \mathrm{c}$ \\
\hline $\mathrm{E}_{1} \mathrm{I}_{3}$ & $66.77 \mathrm{abc}$ & $2.57 \mathrm{bc}$ & 183.52 & $116.80 \mathrm{a}$ & $63.66 a$ & 35.33 & $82.13 c$ \\
\hline$E_{1} I_{2}$ & $58.00 \mathrm{~b}-\mathrm{e}$ & 2.21de & 190.83 & $73.91 \mathrm{~cd}$ & $38.72 \mathrm{c}$ & 43.00 & $91.50 \mathrm{ab}$ \\
\hline $\mathrm{E}_{1} \mathrm{I}_{1}$ & 59.53b-e & $1.84 \mathrm{f}$ & 184.15 & $70.32 \mathrm{~cd}$ & $38.20 c$ & 42.67 & $92.97 a$ \\
\hline $\mathrm{E}_{0} \mathrm{I}_{0}$ & $48.17 \mathrm{e}$ & $1.23 \mathrm{e}-\mathrm{h}$ & 148.17 & $28.85 f$ & $20.00 \mathrm{e}$ & 50.33 & $96.17 \mathrm{a}$ \\
\hline $\mathrm{E}_{0} \mathrm{I}_{4}$ & $69.30 \mathrm{ab}$ & $2.72 b$ & 174.95 & $79.58 c$ & $45.65 b c$ & 36.33 & $83.53 c$ \\
\hline $\mathrm{E}_{0} \mathrm{I}_{3}$ & $62.50 a-d$ & $2.40 \mathrm{~cd}$ & 180.17 & $98.99 b$ & $55.19 \mathrm{ab}$ & 41.00 & $85.00 \mathrm{bc}$ \\
\hline $\mathrm{E}_{0} \mathrm{I}_{2}$ & $53.00 \mathrm{de}$ & $2.09 \mathrm{e}$ & 168.79 & 59.92de & $35.40 \mathrm{~cd}$ & 46.33 & $91.23 \mathrm{ab}$ \\
\hline $\mathrm{E}_{0} \mathrm{I}_{1}$ & $54.57 \mathrm{c}-\mathrm{e}$ & $1.51 \mathrm{~g}$ & 169.97 & $60.74 \mathrm{de}$ & $35.80 \mathrm{~cd}$ & 48.00 & $92.63 a$ \\
\hline LSD at $5 \%$ & 11.54 & 0.19 & NS & 16.82 & 9.94 & NS & 6.08 \\
\hline $1 \%$ & 15.90 & 0.26 & & 23.18 & 13.69 & & 8.37 \\
\hline
\end{tabular}

Means followed by the same letter(s) do not statistically differ at $5 \%$ level tested by DMRT, $\mathrm{NS}=$ Non Significant, $\mathrm{E}_{1}=$ Earthing up, $\mathrm{E}_{0}=$ Non-earthing up, $\mathrm{I}_{0}=$ No irrigation, $\mathrm{I}_{4}=$ Irrigation start at first time and when required, $\mathrm{I}_{3}=$ Irrigation start at $40 \mathrm{DAP}$ and when required, $\mathrm{I}_{2}=$ Irrigation start at $60 \mathrm{DAP}$ and when required, $\mathrm{I}_{1}=$ Irrigation start at $80 \mathrm{DAP}$ and when required

\section{Days to complete blooming}

Maximum days (89.71) was required non earthing up and minimum was found from earthing up. Different irrigation level was significant variation was found to be blooming. 
The longest time (93.92) was required from control irrigation, followed by irrigation start at 60 and 80 DAP whereas the shortest time (82.35) was required from irrigation start at planting and when necessary and it was similar to irrigation start at 40 DAP and when required. The longest time (96.17) was required from treatment combination $\mathrm{E}_{0} \mathrm{I}_{0}$ and shortest time (81.17) was found from treatment combination $\mathrm{E}_{1} \mathrm{I}_{4}$ followed by $\mathrm{E}_{1} \mathrm{I}_{3}, \mathrm{E}_{0} \mathrm{I}_{4}$ and $\mathrm{E}_{0} \mathrm{I}_{3}$.

\section{Days to seed harvest}

Maximum days (141.31) from earthing up and minimum was (137.95 days) found from having no earthing up. The longest time of seed harvest (141.77 days) was found form irrigation start at first time and when necessary. The shortest time to seed harvest (136.22 days) was found from control irrigation. The interaction effect of earthing up and irrigation was found to be insignificant of days to seed harvest.

\section{Seed yield per umbel $(g)$}

There were significant effect in earthing up, irrigation and their interaction effect in relation to seed yield per umbel (Table 3). Maximum yield per umbel $(0.45 \mathrm{~g})$ was obtained from earthing up treated plant whereas minimum seed yield $(0.39 \mathrm{~g})$ was found from having no earthing up. The highest yield per umbel $(0.52 \mathrm{~g})$ were found from irrigation start at first time and when required and irrigation start at $40 \mathrm{DAP}$ and when required, it was different from all other treatments and compared to control. Increasing seed yield per plant with irrigation treatment was reported by Brown et al. (1977). In the combined effect, the highest seed yield per umbel $(0.56 \mathrm{~g})$ was found from $\mathrm{E}_{1} \mathrm{I}_{4}$, which was statistically similar with $\mathrm{E}_{1} \mathrm{I}_{3}$ treatment combination and $\mathrm{E}_{0} \mathrm{I}_{3}$. The lowest seed yield $(0.19 \mathrm{~g})$ come from control $\left(\mathrm{E}_{0} \mathrm{I}_{0}\right)$ treatment combination.

\section{Seed yield per plant $(g)$}

There was a significant variation in respect of seed yield per plant between earthing up and non-earthing up, different irrigation level and their combined effect. The maximum yield per plant $(1.07 \mathrm{~g})$ was found at earthing up and this value was significantly different from non-earthing up. The highest seed yield per plant $(1.47 \mathrm{~g})$ was observed at irrigation start at first time and when required and the lowest seed yield per plant $(0.40 \mathrm{~g})$ was found from control irrigation. Eunus et al. (1974) reported that land with high soil moisture content due to irrigation gave better yield than dry land. The highest seed yield per plant $(1.62 \mathrm{~g})$ was found at $\mathrm{E}_{1} \mathrm{I}_{4}$ treatment combination whereas the lowest seed yield per plant $(0.24 \mathrm{~g})$ was found from treatment combination $\mathrm{E}_{0} 1_{0}$.

\section{Seed yield per plot $(\mathrm{g})$ and per hectare $(\mathrm{kg})$}

There was a highly significant difference between earthing up treatment, different irrigation level and their combined effect in relation to the seed yield per plot (Table 3). Maximum seed yield per plot $(26.64 \mathrm{~g})$ was found from earthing up treated plant while the minimum seed yield per plot $(20.71 \mathrm{~g})$ was found from no earthing up plant. Seed yield per plot was converted into per hectare. The highest seed yield per plot (36.84 g) was found form irrigation start at first time and when required while the lowest seed 
yield $(9.95 \mathrm{~g})$ was found from control irrigation. Seed yield per plot was converted into per hectare. The highest seed yield per plot $(40.60 \mathrm{~g})$ was found from earthing up with irrigation start at first time and when required and this combination was significantly different from all other combination and compared to control. The lowest seed yield per plot $(5.85 \mathrm{~g})$ was found from control treatment. The seed yield per plot was converted into seed yield per hectare (Table 3). Well-established plant carried out a better physiological and metabolic activities all through their life cycle. Consequently more dry matter accumulation might have taken place during vegetative growth and seed formation compared to non-irrigated plants. This might have attributed to higher seed yield. Mondal and Hussain (1980) reported to have obtained similar results from their experiment regarding this character.

Table 3. Effect of earthing up at different levels of irrigation on the seed yield and quality of onion

\begin{tabular}{|c|c|c|c|c|c|c|c|}
\hline Treatment s & $\begin{array}{c}\text { Days to seed } \\
\text { harvest }\end{array}$ & $\begin{array}{c}\text { Seed yield/ } \\
\text { umbel (g) }\end{array}$ & $\begin{array}{l}\text { Seed yield } \\
\text { /plant (g) }\end{array}$ & \begin{tabular}{|c|} 
Seed yield \\
/ plot $(\mathrm{g})$
\end{tabular} & $\begin{array}{l}\text { Seed yield } \\
\text { / ha (kg) }\end{array}$ & $\begin{array}{c}1000 \text { Seed } \\
\text { Wt. (g) }\end{array}$ & $\begin{array}{c}\text { Germination } \\
(\%)\end{array}$ \\
\hline $\mathrm{E}_{1}$ & 141.31 & 0.45 & 1.07 & 26.64 & 266.36 & 2.87 & 72.65 \\
\hline $\mathrm{E}_{0}$ & 137.95 & 0.39 & 0.83 & 20.71 & 207.10 & 2.65 & 68.00 \\
\hline LSD at $5 \%$ & NS & 0.06 & 0.16 & 4.13 & 39.68 & NS & 4.99 \\
\hline $1 \%$ & & 0.13 & 0.36 & 9.52 & 91.53 & & - \\
\hline \multicolumn{8}{|c|}{ Irrigation level } \\
\hline $\mathrm{I}_{0}$ & 136.22 & $0.25 \mathrm{~d}$ & $0.40 \mathrm{e}$ & $9.95 \mathrm{e}$ & $99.47 \mathrm{e}$ & $1.85 \mathrm{c}$ & $51.29 \mathrm{~d}$ \\
\hline $\mathrm{I}_{4}$ & 141.77 & $0.52 \mathrm{a}$ & $1.47 \mathrm{a}$ & $36.84 a$ & $368.35 a$ & $3.27 \mathrm{a}$ & $80.22 \mathrm{a}$ \\
\hline $\mathrm{I}_{3}$ & 140.77 & $0.52 \mathrm{a}$ & $1.30 \mathrm{~b}$ & $32.37 \mathrm{~b}$ & $323.68 b$ & $3.01 \mathrm{ab}$ & $78.90 \mathrm{ab}$ \\
\hline $\mathrm{I}_{2}$ & 139.78 & $0.44 \mathrm{~b}$ & $0.94 \mathrm{c}$ & $23.49 \mathrm{c}$ & $234.87 \mathrm{c}$ & 2.95ab & $75.28 b$ \\
\hline $\mathrm{I}_{1}$ & 139.62 & $0.38 \mathrm{c}$ & $0.63 \mathrm{~d}$ & $15.73 d$ & $157.28 \mathrm{~d}$ & $2.72 b$ & $65.95 c$ \\
\hline LSD at $5 \%$ & NS & 0.04 & 0.09 & 1.75 & 17.53 & 0.34 & 3.84 \\
\hline $1 \%$ & & 0.05 & 0.13 & 2.42 & 24.16 & 0.46 & 5.29 \\
\hline \multicolumn{8}{|c|}{ Treatment combinations } \\
\hline $\mathrm{E}_{1} \mathrm{I}_{0}$ & 141.47 & $0.31 \mathrm{e}$ & $0.56 \mathrm{~g}$ & $14.04 \mathrm{~g}$ & $140.43 \mathrm{~g}$ & $2.25 c$ & 57.37e \\
\hline $\mathrm{E}_{1} \mathrm{I}_{4}$ & 143.47 & $0.56 \mathrm{a}$ & $1.62 \mathrm{a}$ & $40.60 \mathrm{a}$ & $405.97 a$ & $3.31 \mathrm{a}$ & $80.22 \mathrm{a}$ \\
\hline $\mathrm{E}_{1} \mathrm{I}_{3}$ & 141.57 & $0.54 \mathrm{ab}$ & $1.39 \mathrm{~b}$ & $34.74 b$ & $347.37 \mathrm{~b}$ & $2.90 \mathrm{ab}$ & $79.27 \mathrm{a}$ \\
\hline$E_{1} I_{2}$ & 140.70 & $0.47 \mathrm{c}$ & $1.04 d$ & $25.98 \mathrm{~d}$ & $259.83 d$ & $3.05 \mathrm{ab}$ & 77.87ab \\
\hline $\mathrm{E}_{1} \mathrm{I}_{1}$ & 139.37 & $0.39 \mathrm{~d}$ & $0.71 \mathrm{f}$ & $17.82 \mathrm{f}$ & $178.20 \mathrm{f}$ & 2.82ab & $68.53 \mathrm{~cd}$ \\
\hline $\mathrm{E}_{0} \mathrm{I}_{0}$ & 130.97 & $0.19 f$ & $0.24 \mathrm{~h}$ & $5.85 \mathrm{~h}$ & $58.50 \mathrm{~h}$ & $1.45 \mathrm{~d}$ & $45.20 \mathrm{f}$ \\
\hline $\mathrm{E}_{0} \mathrm{I}_{4}$ & 140.07 & $0.49 b c$ & $1.32 b$ & $33.07 \mathrm{~b}$ & $330.73 b$ & $3.22 \mathrm{a}$ & $80.22 \mathrm{a}$ \\
\hline $\mathrm{E}_{0} \mathrm{I}_{3}$ & 139.97 & $0.50 \mathrm{abc}$ & $1.20 \mathrm{c}$ & $30.00 \mathrm{c}$ & $300.00 \mathrm{c}$ & $3.13 \mathrm{ab}$ & $78.53 a$ \\
\hline $\mathrm{E}_{0} \mathrm{I}_{2}$ & 138.87 & $0.40 \mathrm{~d}$ & $0.84 \mathrm{e}$ & $20.99 e$ & 209.90e & $2.84 \mathrm{ab}$ & $72.68 b c$ \\
\hline $\mathrm{E}_{0} \mathrm{I}_{1}$ & 139.87 & $0.37 \mathrm{~d}$ & $0.55 \mathrm{~g}$ & $13.64 \mathrm{~g}$ & $136.37 \mathrm{~g}$ & $2.62 \mathrm{bc}$ & $63.37 \mathrm{~d}$ \\
\hline LSD at $5 \%$ & NS & 0.05 & 0.09 & 2.48 & 24.80 & 0.47 & 5.43 \\
\hline $1 \%$ & & 0.08 & 0.13 & 3.42 & 34.16 & 0.65 & 7.48 \\
\hline
\end{tabular}

Means followed by the same letter(s) do not statistically differ at 5\% level tested by DMRT, NS = Non Significant, $\mathrm{E}_{1}=$ Earthing up, $\mathrm{E}_{0}=$ Non-earthing up, $\mathrm{I}_{0}=$ No irrigation, $\mathrm{I}_{4}=$ Irrigation start at first time and when required, $\mathrm{I}_{3}=$ Irrigation start at $40 \mathrm{DAP}$ and when required, $\mathrm{I}_{2}=$ Irrigation start at $60 \mathrm{DAP}$ and when required, $\mathrm{I}_{1}=$ Irrigation start at $80 \mathrm{DAP}$ and when required 


\section{Weight of 1000 seed}

The influence of the earthing up was not significant effect on 1000 seed weight but irrigation level and their combined effect were significant when 1000 seed weight was considered (Table 3). The maximum seed weight of $2.87 \mathrm{~g}$ was obtained from earthing up applied plant while the minimum $(2.65 \mathrm{~g} / 1000$ seed $)$ was obtained from having no earthing up. The highest seed weight $(3.27 \mathrm{~g}) / 1000$ seed) was found from irrigation start at first time and when required which was statistically similar with irrigation start 40 and $60 \mathrm{DAP}$ and when required. The lowest seed weight $(1.85 \mathrm{~g} / 1000$ seed) was found from control irrigation (Table 3). In the combined effect, the highest seed weight $(3.31 \mathrm{~g} / 1000$ seed) was found from treatment combination $\mathrm{E}_{1} \mathrm{I}_{4}$ and it was statistically identical with all treatment combination except $\mathrm{E}_{1} \mathrm{I}_{0}$ and $\mathrm{E}_{0} \mathrm{I}_{0}$ treatment combination.

\section{Percentage of germination}

There was a marked influence on the percentage of seed germination by earthing up treatment (Table 3). The percent seed germination was found to be the maximum $(72.65 \%)$ in earthing up and the minimum $(68.00 \%)$ was found in no earthing up plant. There was highly significant variation among different level of irrigation (Table 3 ). The highest percentage $(80.22 \%)$ was found from irrigation start at first time and when required, statistically similar with irrigation start at 40 DAP and when required. Irrigation application resulting in producing heavier and larger sized seed might have had such initial food reserve and ultimately helped better germination. In contrast MacGillivray (1948) reported that there was no significant difference in seed germination among different irrigation treatments. The lowest percentage of germination $(51.29 \%)$ was obtained from control irrigation. In the combined effect, the highest percentage of germination $(80.22 \%)$ was found from $\mathrm{E}_{1} \mathrm{I}_{4}$ treatment combination followed by $\mathrm{E}_{1} \mathrm{I}_{3}, \mathrm{E}_{0} \mathrm{I}_{4}$ and $\mathrm{E}_{0} \mathrm{I}_{3}$ and statistically identical with $\mathrm{E}_{1} \mathrm{I}_{2}$. The lowest percentage of germination $(45.20 \%)$ was found from control treatment combination.

\section{REFERENCES}

Anonymous, 2004. BARI onion-2, A new addition summer onion farming may recover our total shortage. The Bangladesh Observer, Last page.

Bhonde, S. R., Lecehiman, R., Srivastava, K. J. and Ram, L. 1989. Effect of spacing and levels of nitrogen on seed yield of onion. Seed and Farms, 15(1) : 21-22.

Bokshi, A. I., Mondal, M. F. and Pramanik, M. H. R. 1989. Effect of nitrogen and phosphorus nutrition on the yield and quality of onion seeds. Bangladesh Hort., 17(2) : 30-35.

Brown, M. J., Wright, J. L. and Khol, R. A. 1977. Onion seed yield and quality as affected by irrigation management. Agron. J., 34(8) : 260-268.

Eunus, M., Kamal, M. A. and Shahiduzzaman, M. 1974. Effect of spacing and dry versus wet planting on the yield of onion (Allium cepa L.). Indian J. Hort., 31(2) : 8-12.

FAO. 1999. FAO Trade Yearbook. Food and Agriculture Organization of the United Nations, Rome, Italy. $50: 1$

Globerson, D., Levy, M., Huppert, H. and Fliassy, R. 1987. When the discontinue irrigation of onion grown for seed production. Acta Hort., 215 : 17-24. 
Gomez, K. and Gomez, A. A. 1984. Statistical Procedures for Agricultural Research. John Willey and Sons, New York. pp. 633-636.

Hossain, A. K. M. A. and Islam, J. 1994. Status of Allium production in Bangladesh. Acta Hort., 358 : 33-36.

HRDP. 1995. Training Manual : Winter Vegetable and Spices production. Horticulture Research and Development Project (FAO/UNDP/AsDB Project. BGD/87/025) and BADC, Dhaka, $284 \mathrm{p}$.

Hunter, A. H. 1984. Soil Fertility Analytical Services in Bangladesh. Consultancy Report. BARC. Dhaka.

Jonassen, G. H. 1983. Effect of different storage temperature and pre-growing treatments on the seed yield. Forskining og Forsok I Landbruket, 34(1) : 21-25 [Cited from Seed Abstr., 7(7) : 1894, 1984].

Jones, H.A. and Mann, L. K. 1963. Onions and their Allies. Leonard Hill, London. pp. 162-169.

MacGillivray, J. H. 1948. Effect of irrigation on the yield onion seed. Proc. Amer. Soc. Hort. Sci., 51 : 423-427.

Mital, S. P. and Shrivastava, G. 1964. Seed yield in relation to bulb sizes and number of seed-stalks in onion (Allium cepa L.). Indian J. Hort., 21 : 264-269.

Mondal, M. F. and Hussain, A. 1980. Effect of the time of planting onion bulbs on the yield and quality of seeds. Bangladesh J. Agric., $5: 131-134$.

Pandey, U. B., L. Singh and Bhonde, S. R. 1992. Studies of effect of stages of harvesting on germination and vigour of onion seed. Newsletter Associated Agricultural Development Foundation, Nasik, India. 12(4) : 2-4.

Patil, J. G., Shelar, V. R. and Shinde, S. K. 1993. Seed yield and yield contributing characters as influenced by irrigation intensity in onion seed crop. Maharashtra J. Hort., 7(1) : 67-71.

Rahim, M. A., Amin, M. M. U. and Haider, M. A. 1993. Onion seed production technology in Bangladesh. Allium improvement Newsletter, USA. 3 : 26-33.

Shasha, A. N. S., Campbell, W. F. and Nye, W. P. 1986. Effect of fertilizer and moisture on seed yield of onion. Hort. Sci., 11(4) : 425-426. 